\title{
ПЕРСПЕКТИВНИЙ НАПРЯМОК РОЗВИТКУ АМБУЛАТОРНОЇ КАРДІОЛОГІЧНОЇ ДОПОМОГИ НАСЕЛЕННЮ РЕГІОНУ В СУЧАСНИХ ЕКОНОМІЧНИХ УМОВАХ
}

\author{
Київська обласна клінічна лікарня, м. Київ, Україна
}

\begin{abstract}
Мета: здійснити медико-соціальне обґрунтування пріоритетного напрямку розвитку амбулаторної кардіологічної допомоги населенню регіону в сучасних економічних умовах.

Матеріали і методи. Пріоритетний напрямок розвитку регіональної амбулаторної кардіологічної допомоги населенню регіону в нових економічних умовах обґрунтований методом системного аналізу, а також інформаційноаналітичним, соціологічним та статистичним методами. Інформаційною базою для його фрормування виступили наукові роботи вітчизняних і зарубіжних фрахівців із кардіології, державно-приватного партнерства (ДПП) і менеджменту, а також власні дослідження, у ході яких отримано характеристику мережі та ресурсного забезпечення амбулаторно-поліклінічних закладів (АПЗ), які надають кардіологічну допомогу населенню Київської області (у динаміці за 2014-2019рр.), здійснено соціологічне опитування 829 пацієнтів (які були під спостереженням із приводу хвороб системи кровообігу (ХСК) у сімейних лікарів та районних кардіологів у Київській області), а також соціологічне опитування 352 лікарів-кардіологів з усіх регіонів України.

Результати. Встановлено хронічне недофрінансування та незадовільний рівень розвитку матеріально-технічної бази АПЗ, які надають кардіологічну допомогу населенню Київської області. Виявлено ряд проблем та низький рівень задоволеності організацією амбулаторної кардіологічної допомоги населенню за результатами соціологічного опитування пацієнтів із ХСК та лікарів-кардіологів. Розглянуто механізми державно-приватного партнерства як спосіб залучення інвестицій до системи охорони здоров'я і визначено наявність в Україні правової бази для реалізації ДПП в охороні здоров'я. У результаті обґрунтовано основні напрямки розвитку амбулаторної кардіологічної допомоги населенню регіону в сучасних економічних умовах на основі використання механізмів ДПП.
\end{abstract}

Висновки. Пріоритетним напрямком удосконалення організації амбулаторної кардіологічної допомоги населенню регіонів у сучасних економічних умовах є фрормування в АПЗ господарського механізму на принципах ДПП.

КЛЮЧОВІ СЛОВА: амбулаторна кардіологічна допомога; державно-приватне партнерство.

Хвороби системи кровообігу (ХСК) є основною причиною смерті та інвалідизації дорослого населення та населення працездатного віку в Україні, що зумовлює їх вагоме медико-соціальне та соціально-економічне значення [3, 4, 12]. У XXI столітті хвороби системи кровообігу залишаються основною причиною смерті населення більшості країн Європи. За оцінками ВОО3, у 2015 р. на глобальному рівні відбулося $40 \mathrm{Mлн}$ смертей від хронічних неінфекційних захворювань (ХНІ3), що становить $70 \%$ від загальної кількості (56 млн) смертей у світі. Більшість цих випадків була зумовлена хворобами системи кровообігу (17,7 млн). Понад 75 \% випадків смерті від ХСК реєструють у країнах із низьким і середнім рівнем доходу [5].

За оцінками, наведеними в інформаційному бюлетені ВООЗ, у 2016 р. від ХСК померло 17,9 млн осіб, що склало 31 \% серед усіх випадків смерті у світі. 85 \% цих смертей сталося в результаті серцевого нападу та інсульту $[11,14]$.

В Україні на XНІ3 припадає основна частина смертей (84 \%) з високою їх концентрацією серед чоловіків працездатного віку. Зокрема, показник

(с) А. В. Іванюк, 2021 смертності від ХНІЗ в Україні (749 на 100 тис. населення) у 1,4 раза перевищує середній у світі (539 на 100 тис. населення) і навіть показник у таких неблагополучних регіонах, як ПівденноСхідна Азія (656) і Афрриканський регіон (652).

А серед усіх випадків смерті від неінфрекційних хвороб на випадки смерті від ішемічної хвороби серця припадає 45,94 \%, а захворювання серцево-судинної системи забирають життя у 16,52 \% українців $[1,13]$.

Таким чином, актуальність теми дослідження зумовлена потребою у науковому обґрунтуванні заходів медико-організаційного характеру щодо підвищення доступності та якості кардіологічної допомоги, включаючи ії високотехнологічні види, особливо населенню, яке проживає у сільській місцевості.

Мета дослідження: здійснити медико-соціальне обґрунтування пріоритетного напрямку розвитку амбулаторної кардіологічної допомоги населенню регіону в сучасних економічних умовах.

Матеріали і методи. Пріоритетний напрямок розвитку регіональної амбулаторної кардіологічної допомоги населенню регіону в нових економічних умовах обґрунтований методом систем- 
ного аналізу, а також інорормаційно-аналітичним, соціологічним та статистичним методами. Інформаційною базою для його фрормування виступили наукові роботи вітчизняних і зарубіжних фахівців із кардіології, державно-приватного партнерства (ДПП) і менеджменту, а також результати власних досліджень мережі амбулаторно-поліклінічних закладів (АПЗ), які надають кардіологічну допомогу населенню Київської області, та соціологічних опитувань лікарів-кардіологів та пацієнтів із ХСК.

Аналіз мережі та ресурсного забезпечення амбулаторно-поліклінічних закладів, які надають кардіологічну допомогу населенню Київської області, здійснено у динаміці за 2014-2019 рр. за матеріалами фрорм статистичної звітності (фp. № 17, фр. № 20).

Соціологічне дослідження здійснено в 2020 р., його результати охопили репрезентативні сукупності респондентів. Соціологічне опитування проведено серед 829 пацієнтів, які були під спостереженням із приводу хвороб системи кровообігу в сімейних лікарів та районних кардіологів у Київській області, а також серед 352 лікарівкардіологів з усіх регіонів України. Статистична обробка матеріалів соціологічного дослідження передбачала використання методів статистичного групування, аналізу абсолютних і відносних рядів розподілу, визначення помилок репрезентативності, оцінку статистичної достовірності відмінностей результатів соціологічного опитування (за критерієм Пірсона $X^{2}$ ).

Результати дослідження та їх обговорення. Амбулаторна ланка $€$ важливою складовою кардіологічної допомоги населенню. Саме від стану організації амбулаторного етапу кардіологічної допомоги залежить своєчасність виявлення ХCK, ефрективність диспансерного спостереження за хворими, а також здійснення всього комплексу профрілактичних заходів, спрямованих на збереження здоров'я населення і запобігання розвитку ХCК.

На основі аналізу мережі та кадрового забезпечення кардіологічної служби Київської області (чисельність наявного населення області на 1 січня 2019 р. становила 1781044 осіб) у 2014-2019 рр., встановлено, що в амбулаторних умовах працює 27 кардіологічних кабінетів ЦРЛ, у яких передбачено 38 посад лікарів-кардіологів. Серед 29 районів Київської області - 10 районів забезпечені мінімальним діагностичним обладнанням для діагностики кардіологічної патології - електрокардіографами. У 14 районах відсутні ехокардіографи, у 16 районах не працюють, або відсутні велоергометри. Половина районів не має можливості проводити дослідження крові на ліпіди. Холтерівське моніторування ЕКГ та артеріального тиску хворим у змозі проводити тільки 4 райони області. Таким чином, розвиток матеріально-технічної бази кардіологічної служби Київської області є вкрай недостатнім.

Оцінка задоволеності населення отриманою медичною допомогою, а також вивчення думки лікарів щодо проблем та можливостей удосконалення її організації є необхідною умовою для здійснення науково обґрунтованої управлінської діяльності у системі охорони здоров'я і однією зі складових для обґрунтування нових організаційних форм і методів роботи органів та закладів охорони здоров'я [10]. У 2020 р. за спеціально розробленою анкетою ми провели соціологічне опитування 829 пацієнтів, які звернулися до амбулаторно-поліклінічних закладів Київської області з приводу хвороб системи кровообігу.

Результати проведеного соціологічного опитування дозволили отримати характеристику організації амбулаторної кардіологічної допомоги населенню Київської області за невідображеними у матеріалах статистичної звітності аспектами.

Встановлено, що пацієнтів із ХСК спостерігали лікарі амбулаторної ланки регулярно в 40,4 \% випадків, нерегулярно - у 43,6 \%, не спостерігали взагалі - у 16 \%. Тільки 15,8 \% респондентів задоволені медичною допомогою, яку надають в амбулаторно-поліклінічних умовах. Більшість пацієнтів (52,8 \%) задоволена частково і одна третина (31,4 \%) - незадоволена зовсім.

Основними причинами невдоволеності, отриманою у АПЗ медичною допомогою, пацієнти із ХСК назвали: тривале очікування на прийом лікаря у черзі (62,2 \%), низьку доступність безкоштовного забезпечення медикаментами (54,6 \%), низьку доступність планового стаціонарного лікування (34,9\%), неуважне ставлення медичного персоналу (24,3\%), недостатню результативність лікування (19,8 \%). Таким чином, результати проведеного соціологічного дослідження дозволили встановити, що організація кардіологічної допомоги населенню Київської області не цілком задовольняє населення і вимагає оптимізації.

Також було проведено соціологічне дослідження, яке охопило 352 лікарів-кардіологів 3 усіх регіонів України.

Аналіз результатів соціологічного опитування лікарів-кардіологів засвідчив, що основними проблемами організації кардіологічної допомоги сільському населенню є: недофрінансування

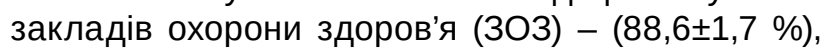
нерівномірна укомплектованість лікарями і середніми медичними працівниками (56,8 2,6 \%), низький рівень оплати праці медичного персоналу $(87,2 \pm 1,8 \%)$, велике навантаження $(66,2 \pm 2,5 \%)$, недостатнє оснащення закладів медичною апаратурою (77,0 $\pm 2,2 \%)$.

Основними напрямками удосконалення організації кардіологічної допомоги сільському населенню, на думку лікарів-кардіологів України, 


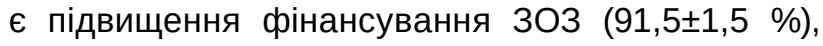

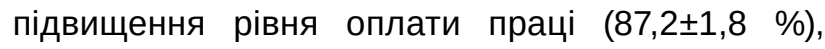
запровадження обов'язкового медичного страхування (81,8土2,1 \%), запровадження механізмів

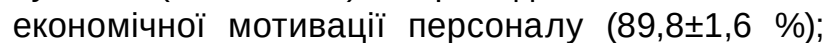
оснащення 303 сучасним лікувально-

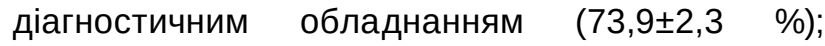
підвищення якості післядипломної підготовки лікарів-кардіологів (78,2ะ1,9\%); запровадження системи моніторингу якості медичної допо-

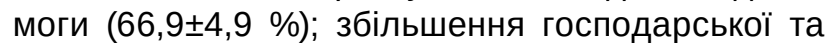

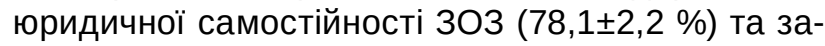
провадження механізмів державно-приватного партнерства зі збереженням 303 у власності

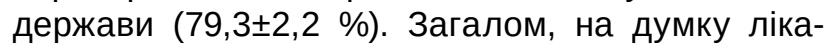
рів-кардіологів, існуюча система надання кардіологічної допомоги сільському населенню потребує модернізації її організаційних складових.

У визначенні державно-приватного партнерства, наведеному в Практичному керівництві Європейської економічної комісії 3 питань ефективного управління у сорері державно-приватного партнерства, зазначено, що: «державно-приватне партнерство здійснюється 3 метою забезпечення фрінансування, планування, виконання та експлуатації об'єктів, виробництв та надання послуг державного сектору» [4].

Вирішення нагальних проблем в організації амбулаторної кардіологічної допомоги населенню ми бачимо насамперед у розвитку ДПП в охороні здоров'я у рамках, визначених законами України. На даний момент в Україні створено правові та інституційні основи для реалізації інвестиційних механізмів ДПП в охороні здоров'я: Закон України від 01.07.2010 р. № 2404-VI «Про державно-приватне партнерство» [9]; Закон України від 24.11.2015 р. № 817-VIII «Про внесення змін до деяких законів України щодо усунення регуляторних бар'єрів для розвитку державно-приватного партнерства та стимулювання інвестицій в Україні» [7]; Закон України від 06.04.2017 р. № 2002-VIII «Про внесення змін до деяких законодавчих актів України щодо удосконалення законодавства 3 питань діяльності закладів охорони здоров'я» [8].

Шляхом до підвищення ефективності системи кардіологічної допомоги $€$ створення нової організаційної структури на базі механізму ДПП, і це $є$ фрункцією менеджменту. На думку провідних американських фрахівців, менеджмент - це не управління предметами, а організація і управління працею людей, це система щоденного та перспективного планування, прогнозування та організації виробництва, реалізація послуг з метою отримання максимального прибутку (матеріального, інтелектуального та духовного) [2].

Менеджмент як сучасна концепція управління, як процес ефрективного планування, організації виробництва і моніторування виконання виробничих завдань потребує від керівника АПЗ, який працює у ринкових умовах, чіткого визначення заходів відповідальності за досягнення конкретних запланованих результатів діяльності АПЗ та за ефективне використання ресурсів. У зв'язку 3 чим актуальною проблемою вітчизняної системи охорони здоров'я $є$ удосконалення підготовки менеджерів через сучасні державні програми навчання і перепідготовки управлінського кадрового потенціалу. Удосконалення системи підготовки менеджерів дозволить перевести амбулаторну кардіологічну допомогу населенню з бюджетної структури держави у сучасний сектор охорони здоров'я, адекватно вбудований у ринок медичних послуг.

\section{Висновки}

Проведений аналіз організації амбулаторної кардіологічної допомоги населенню Київської області, здійснений за матеріалами соціологічного опитування пацієнтів та лікарів-кардіологів, а також комплексної оцінки стану кадрових і матеріальних ресурсів діючої мережі АПЗ області, які надають медичну допомогу пацієнтам із ХСК, засвідчив незадовільний стан досліджуваного об'єкта.

Перспективним напрямком розвитку амбулаторної кардіологічної допомоги потрібно вважати перехід на принципи ДПП як механізму реалізації інноваційної економіки, сучасного механізму залучення інвестицій, здатного забезпечити економічну стійкість АПЗ, підвищити рівень матеріально-технічного оснащення АПЗ, забезпечити впровадження економічних і лікувальних стандартів у практику роботи, що визначить соціальну ефективність кардіологічної допомоги. Запровадження в АПЗ, які надають кардіологічну допомогу населенню Київської області, механізмів ДПП дозволить оптимізувати їх організацію та управління, а також забезпечити зростання економічної ефективності.

Перспективи подальших досліджень полягають у використанні отриманих результатів для обґрунтування концептуальних підходів до удосконалення організації кардіологічної допомоги на обласному рівні.

\section{Список літератури}

1. Гандзюк В. А. Динаміка захворюваності та поширеності хвороб системи кровообігу серед населення України на сучасному етапі: національний та регіональний аспекти / В. А. Гандзюк // Вісник соціальної гігієни та організації охорони здоров'я України. - 2014. - № 2 (60). - С. 74-79. 
2. Друкер П. Друкер на каждый день. 366 советов успешному менеджеру / Питер Друкер, Джозеф Макьярелло ; пер. с англ. А. Рыбянец. - 2-е изд. - М. : Манн, Иванов и Фарбер, Эксмо, 2013. - 432 с.

3. Дудник С. В. Хвороби системи кровообігу як соціально-медична проблема / С. В. Дудник, І. І. Кошеля // Україна. Здоров'я нації. - 2017. - № 3 (44). - С. 20-21.

4. Коваленко В. М. Серцево-судинні хвороби: медично-соціальне значення та стратегія розвитку кардіології в Україні / В. М. Коваленко, А. П. Дорогой // Український кардіологічний журнал. - 2016. - Додаток 3. - С. 5-14.

5. Мировая статистика здравоохранения, 2017 г. : мониторинг показателей здоровья [Электронный ресурс] / ВОЗ. 130 с. - Режим доступа : https://www.who.int/gho/publications/world_health_statistics/2017/ru/.

6. Практическое руководство по вопросам эффективного управления в сфере государственно-частного партнерства. - Нью-Йорк, Женева : ООН, 2008. - 114 с.

7. Про внесення змін до деяких законів України щодо усунення регуляторних бар'єрів для розвитку державноприватного партнерства та стимулювання інвестицій в Україні : Закон України від 24.11.2015 р. № 817-VIII [Електронний ресурс]. - Режим доступу : https://zakon.rada.gov.ua/laws/show/817-19.\#Text.

8. Про внесення змін до деяких законодавчих актів України щодо удосконалення законодавства з питань діяльності закладів охорони здоров'я : Закон України від 06.04.2017 р. № 2002-VIII [Електронний ресурс]. - Режим доступу : https://zakon.rada.gov.ua/laws/show/2002-19\#Text.

9. Про державно-приватне партнерство : Закон України від 01.07.2010 р. № 2404-VI [Електронний ресурс]. - Режим доступу : https://zakon. rada.gov.ua/laws/show/2404-17\#Text.

10. Решетников А. В. Социология медицины : руководство / А. В. Решетников. - М. : ГЭОТАР-Медиа, 2010. - 864 с. 11. Сердечно-сосудистые заболевания. 2017 г. [Электронный ресурс] / Информационный бюллетень ВОЗ. - Режим доступа : https://www.who.int/ru/news-room/fact-sheets/ detail/ cardiovascular-diseases-cvds).

12. Теренда Н. О. Смертність від серцево-судинних захворювань як державна проблема / Н. О. Теренда // Вісник наукових досліджень. - 2015. - № 4. - С. 11-13.

13. Троян М. Ю. Организационно-экономические направления реформирования системы здравоохранения в Украине на пути выхода из демографического кризиса / М. Ю. Троян, Н. Н. Костюченко // Механізм регулювання економіки. - 2015. - № 1. - С. 116-128.

14. Heart disease and stroke statistics / D. Mozaffarian, E. J. Benjamin, A. S. Go [ et al.] // A report from the American Heart Association. Circulation. - 2016. - Vol. 133 (4). - P. 38-360.

\section{References}

1. Handzyuk, V.A. (2014). Dynamika zakhvoryuvanosti ta poshirenosti khvorob systemy krovoobihu sredy naselennya Ukrayiny na suchasnosty etapi: natsional'nyy ta rehional'nyy aspekty. [Dynamics of morbidity and prevalence of diseases of the circulatory system among the population of Ukraine at the present stage: national and regional aspects]. Visnyk sotsialnoyi hihiyeni ta orhanyzatsii okhorony zdorovya Ukrayiny. - Bulletin of Social Hygiene and Health Care Organization of Ukraine, 2 (60), 74-79 [in Ukrainian].

2. Druker, Piter \& Mak'yarello, Dzhozef (2013). Druker na kozhen den. 366 rad uspishnomu menedzheru [Drucker for every day. 366 tips for a successful manager]. (Edd. A. Rybyanets). 2-e vyd. Moscow: Ivanov i Farber. Eksmo [in Russian].

3. Dudnyk, S.V., \& Koshelya, I.I. (2017). Khvoroby systemy krovoobihu yak sotsialno-medychna problema [Diseases of the circulatory system as a socio-medical problem]. Ukrayina. Zdorovya natsiyi. - Ukraine. Health of the Nation, 3 (44), $20-21$. [in Ukrainian].

4. Kovalenko, V.M., \& Dorohyy, A.P. (2016). Sertsevo-sudynni khvoroby: medychno-sotsialne znachennya ta stratehiya rozvytku kardiolohiyi v Ukrayini [Cardiovascular diseases: medical and social significance and strategy of cardiology development in Ukraine]. Ukrayinskyy kardiolohichnyy zhurnal. - Ukrainian Journal of Cardiology, 3, 5-14 [in Ukrainian].

5. Svitova statystyka okhorony zdorovya 2017. Monitorynh pokaznykiv zdorovya VOOZ. [World health statistics 2017. Monitoring WHO health indicators]. www.who.int. Retrieved from: https://www.who.int/gho/publications/world_health_ statistics/2017/ru/ [in Russian].

6. (2008). Practicheskoie rukovodstvo po voprosam effektivnogo upravlienia v cferie gosudarstvennogo chastnogo partniorstva [A Practical Guide to Good Governance in PPPs UN]. New York and Geneva : OON [in Russian].

7. (2015). Zakon Ukrayiny vid 24.11.2015 No 817-VIII «Pro vnesennya zmin do deyaky Zakoniv Ukrayiny otnosytelno Usunennya rehulyatornykh baryeriv dlya rozvytku derzhavno-pryvatnoho partnerstva ta stymulyuvannya investitsiy $v$ Ukrayini» [Law of Ukraine of 24.11.2015 No 817-VIII „On Amendments to Certain Laws of Ukraine on Removing Regulatory Barriers to the Development of Public-Private Partnerships and Stimulating Investment in Ukraine”]. zakon.rada.gov.ua Retrieved from: https://zakon.rada.gov.ua/laws/show/817-19.\#Text

8. (2017). Zakon Ukrayiny vid 06.04.2017 No 2002 VIII «Pro vnesennya zmin do deyaky zakonodavcho AKTIV Ukrayiny otnosytel'no udoskonalennya zakonodavstva po voprosam DIYAL'NOSTI zakladiv okhorony zdorov'ya». [Law of Ukraine dated 06.04.2017 No 2002-VIII "On Amendments to Certain Legislative Acts of Ukraine Concerning the Improvement of Legislation on the Activities of Health Care Institutions"]. zakon.rada.gov.ua Retrieved from: https://zakon.rada.gov.ua/ laws/show/2002-19\#Text

9. (2010). Zakon Ukrayiny vid 01.07.2010 № $2404 \mathrm{VI}$ «Pro derzhavno-chastnoe partnerstvo» [Law of Ukraine of 01.07.2010 No 2404-VI "On Public-Private Partnership"]. zakon.rada.gov.ua Retrieved from: https://zakon.rada.gov.ua/ laws/show/2404-17\#Text

10. Reshetnikov, A.V. (2010). Sotsiolohiya medytsyny. [Sociology of Medicine]. Moscow: GEOTAR Media [in Russian]. 11. (2017). Sierdechno-sosudistyie zabolievania. [Cardiovascular diseases]. Informatsyonnyi biulieten VOZ - Informational Bulletin WHO fact sheet. Retrieved from: https://www.who.int/ru/news-room/fact-sheets/detail/cardiovascular-diseasescvds). [in Russian]. 
12. Terenda, N.O. (2015). Smertnist vid sertsevo-sudynna zakhvoryuvan yak derzhavna problema [Mortality from cardiovascular diseases as a state problem]. Visnyk naukovykh doslidzhen. - Bulletin of Scientific Research, 4, 11-13.[in Ukrainian].

13. Troyan, M.Yu., \& Kostyuchenko, M.M. (2015). Organizatsyonno-ekonomichieskiye napravlieniya reformirovaniya sistiemy zdravookhranieniya $v$ Ukrainie na puti bykhoda iz diemograficheskogo krizisa [Organizational and economic directions of reforming the health care system in Ukraine on the way out of the demographic crisis]. Mekhanizm rehulyuvannya ekonomiky. - Mechanism of Regulation of Economy, 1, 116-128 [in Russian].

14. Mozaffarian, D., Benjamin, E.J., \& Go, A.S. (2016). Heart disease and stroke statistics. A report from the American Heart Association. Circulation, 133 (4), 38-360.

\section{PROSPECTIVE DIRECTION OF DEVELOPMENT OF AMBULATORY CARDIOLOGICAL CARE TO THE POPULATION OF THE REGION IN THE MODERN ECONOMIC CONDITIONS}

A. V. Ivanyuk

Kyiv Regional Clinical Hospital, Kyiv, Ukraine

Rurpose: to carry out a medical and social substantiation of the priority direction of the development of outpatient cardiological care for the population of the region in the new economic conditions.

Materials and Methods. The priority direction of the development of regional outpatient cardiological care for the population of the region in the new economic conditions is carry out using the method of system analysis, as well as information-analytical, sociological and statistical methods. The information base for its formation was the scientific works of domestic and foreign specialists in cardiology, public-private partnership (PPP) and management, as well as our own research, during which the characteristics of the network and resources of outpatient clinics providing cardiological care were obtained, and a sociological study of 829 patients with cardiovascular diseases in Kiev region and sociological survey of 352 cardiologists from all regions of Ukraine were carried out.

Results. Chronic underfunding and an unsatisfactory level of development of the material and technical base of outpatient clinics providing cardiological care to the population of the Kiev region have been established.

A number of problems and a low level of satisfaction with the organization of outpatient cardiological care for the population were revealed according to the results of a sociological survey of patients with cardio-vascular diseases and cardiologists.

The mechanisms of public-private partnership were considered as a way to attract investments in the health care system and the presence of a legal framework for the implementation of PPP in health care in Ukraine was determined. As a result, the main directions of the development of outpatient cardiological care for the population of the region in modern economic conditions were substantiated on the basis of the use of PPP mechanisms.

Conclusions. The priority direction of improving the organization of outpatient cardiological care in the new economic conditions is the formation of an economic mechanism at the outpatient clinics providing cardiological care on the principles of PPP.

KEY WORDS: outpatient cardiological care; public-private partnership.

Рукопис надійшов до редакції 16.01.2021 p.

Відомості про автора:

Іванюк Анатолій Вікторович - кандидат медичних наук, завідувач Центру кардіохірургії Київської обласної клінічної лікарні. 